\title{
KEKUATAN HUKUM PELIMPAHAN WEWENANG DARI DOKTER KEPADA NERS DITINJAU DARI ASPEK PIDANA DAN PERDATA
}

\author{
Aning Pattypeilohy, Sutarno, Adriano \\ Program Studi Magister Ilmu Hukum, Universitas Hang Tuah Surabaya \\ Jl. Arif Rahman Hakim 150, Surabaya, Jawa Timur, 60111 \\ Email : aning.pattypeilohy@gmail.com
}

\begin{abstract}
This study aims to provide an overview of the power of law in the delegation of authority from the doctor to ners both in writing and not written. In performing health services, especially in performing medical acts, it is necessary to transfer the authority of medical personnel to health personnel in order to create a comprehensive and quality health service, this has been regulated in related legislation. Ners is a profession professional and independent, in carrying out its professional duties ners work in accordance with service standards, standard operating procedures and the provisions of the Act-legislation. As a health worker, the ners may receive a delegation of authority only in writing from the doctor to him or her so that the delegate has the force of law. With the delegation of authority in health services, if there is a loss or legal problems in the future, doctors as authors and recipients of authority can be held accountable both criminal and civil.
\end{abstract}

Keywords: Legal Force, Delegation of Authority, Health Service.

\begin{abstract}
Abstrak
Penelitian ini mengkaji tentang kekuatan hukum dalam pelimpahan wewenang dari dokter kepada ners baik secara tertulis maupun tidak tertulis. Dalam melaksanakan pelayanan kesehatan terutama dalam melakukan tindakan medis, perlu adanya pelimpahan wewenang dari tenaga medis ke tenaga kesehatan untuk menciptakan layanan kesehatan yang komprehensif dan berkualitas ini telah diatur dalam peraturan perundang-undangan terkait. Ners adalah profesi profesional dan mandiri, dalam menjalankan tugasnya, ners bekerja sesuai dengan standar pelayanan, prosedur operasi standar dan ketentuan Undang-Undang. Ners sebagai tenaga kesehatan, hanya dapat menerima pelimpahan wewenang secara tertulis dari dokter kepadanya sehingga pelimpahan tersebut memiliki kekuatan hukum. Dengan adanya pelimpahan wewenang secara tertulis dalam pelayanan kesehatan, bila nantinya menimbulkan kerugian atau masalah hukum dalam pelayanan tersebut, maka dokter selaku pemberi wewenang dan ners selaku penerima wewenang dapat dimintai pertanggungjawaban baik pidana maupun perdata.
\end{abstract}

Kata kunci: Kekuatan Hukum, Pelimpahan Wewenang, Pelayanan Kesehatan 


\section{A. PENDAhULUAN}

Salah satu hak dasar dari manusia adalah hak untuk sehat dan juga hak untuk memperoleh pelayanan kesehatan ${ }^{1}$, kesahatan itu sendiri juga merupakan unsur penilaian kesejahteraan suatu bangsa, untuk itu kesehatan yang merupakan gambaran kesejahteraan warga negara harus diwujudkan agar selaras dengan cita-cita bangsa Indonesia sebagaimana yang dimaksud dalam Pembukaan Undang-Undang Dasar Negara Republik Indonesia.

Kesehatan merupakan modal utama manusia dalam menjalankan aktifitas sehari-hari ${ }^{2}$. Berbagai upaya kesehatan yang optimal penting untuk diselenggarakan dengan pendekatan promotif, preventif, kuratif dan rehabilitatif yang dijalankan secara komprehensif. Keberhasilan upaya kesehatan salah satunya tergantung pada ketersediaan sumber daya kesehatan yang berupa tenaga kesehatan ${ }^{3}$. Penyelenggaraan upaya ini harus dilaksanakaan oleh tenaga kesehatan yang memiliki kewenangan dan kualifikasi. Pada awalnya profesi di dunia kesehatan yang diakui oleh masyarakat adalah profesi kedokteran. Namun belakangan ini pekerjaan keperawatan dan kebidanan mulai dikembangkan secara sungguh-sungguh sebagai profesi sendiri dengan body of knowledge dan bentuk pelayanan tersendiri pula ${ }^{4}$.

Tenaga kesehatan ${ }^{5}$ memiliki peranan yang sangat penting untuk meningkatkan kualitas pelayanan kesehatan yang maksimal kepada masyarakat agar derajat kesejahteraan yang dimaksud dalam pembukaan Undang-Undang Dasar Negara Republik Indonesia dapat diwujudkan. Di dalam menyelenggarakan pelayanan kesehatan, harus dilakukan sesuai bidang keahlian dan keilmuan yang dimiliki, serta setiap tenaga kesehatan yang dimaksud wajib memiliki izin dari pemerintah. Ners atau perawat profesional merupakan salah satu tenaga kesehatan yang profesional dan mandiri yang dalam menjalankan tugasnya memiliki dua kewenangan yaitu kewenangan untuk melakukan asuhan keperawatan yang sesuai dengan bidang keilmuan yang dimilikinya dan kewenangan untuk melakukan tindakan medis. Kewenangan ners untuk melakukan tindakan medis hanya dapat dilakukan ners apabila ners mendapatkan pelimpahan wewenang dari dokter selaku tenaga medis, hal ini tertuang dalam Pasal 32 Undang-Undang Nomor 38 Tahun 2014 tentang Keperawatan memberi peluang bagi perawat untuk melakukan tindakan medik jika memenuhi ketentuan peraturan perundang undangan. Permenkes Nomor 2052/Menkes/Per/X/2011 tentang Izin Praktik dan Pelaksanaan Praktik Kedokteran, dalam Pasal 23 Ayat (1) menyatakan:

\section{"Dokter atau dokter gigi dapat memberikan pelimpahan suatu tindakan kedokteran atau kedokteran gigi kepada perawat, bidan atau tenaga kesehatan tertentu lainnya secara tertulis dalam melaksanakan tindakan kedokteran atau kedokteran gigi”.}

\footnotetext{
${ }^{1}$ Lihat Undang-Undang Dasar Republik Indonesia Tahun 1945 pasal.28 H.

${ }^{2}$ Safitri Hariyani, Sengketa Medik Alternatif Penyelesaian Perselisihan Antara Dokter dengan Pasien, Jakarta: Diadit Media, 2005, h.1.

3 Sri Praptianingsih, Kedudukan Hukum Perawat dalam Upaya Kesehatan di Rumah Sakit, Jakarta: RajaGrafindo Persada, 2006, h.3.

${ }^{4}$ Sofyawan Dahlan, Hukum Kesehatan Rambu-rambu Profesi Dokter, Semarang: Universitas Diponegoro, 1999, h. 21 .

${ }^{5}$ Lihat pasal 1 Undang-Undang Nomor 36 Tahun 2014 tentang Tenaga Kesehatan.
} 
Pelimpahan wewenang oleh dokter kepada ners dapat dilakukan secara delegasi ataupun mandat. Pelimpahan wewenang secara delegasi disertai pelimpahan tanggung jawab sedangkan pada mandat tidak disertai dengan pelimpahan tanggung jawab. Tugas pelimpahan wewenang yang diberikan dokter yang memiliki kewenangan dalam pelimpahan wewenang kepada ners sering terjadi secara lisan dengan berbicara langsung dengan ners ataupun melalui telepon dengan alasan dokter sedang tidak ada di tempat dan berada di tempat yang jauh dari tempat di mana sedang berlangsung pelayanan kesehatan, dalam peraturan perundang-undangan memang belum mengatur secara jelas mengenai pelimpahan wewenang secara lisan namun seiring perkembangan zaman, pelimpahan wewenang secara lisan maupun tertulis tidak menjadi masalah, sejauh hal tersebut masih bisa dipertanggungjawabkan dan tidak menimbulkan kerugian bagi pasien.

Pelimpahan wewenang secara lisan masih tetap bisa dipertanggungjawabkan, misalnya dokter memberikan delegasi atau mandat kepada ners secara lisan tanpa tertulis namun pada ruangan tersebut dilengkapi dengan Closed Circuit Television (CCTV), maka sudah terdapat bukti pelimpahan wewenang dari dokter kepada ners, demikian pula jika pelimpahan wewenang tersebut via telepon, juga bisa dipertanggungjawabkan dengan rekaman pembicaraan antara dokter dengan ners via telepon tadi. Di sini yang menjadi permasalahan adalah kekuatan dari alat bukti yang didapat dari rekaman CCTV maupun dari rekaman pembicaraan di telepon dan juga regulasi dari pelimpahan wewenang dalam dunia medis secara lisan yang belum diatur secara spesifik dalam perundang-undangan.

\section{B. RUMUSAN PERMASALAHAN}

Berdasarkan uraian di atas, maka penulis melakukan penelitian dengan merumuskan permasalahan berikut ini :

1. Bagaimana kekuatan hukum pelimpahan wewenang dari dokter kepada ners dari aspek pidana?

2. Bagaimana kekuatan hukum pelimpahan wewenang dari dokter kepada ners dari aspek perdata?

\section{METODE PENELITIAN}

Tipe penelitian ini merupakan penelitian yuridis normatif yaitu penelitian yang mencari pemecahan atas isu hukum yang timbul untuk memberikan preskripsi ${ }^{6}$ mengenai apa yang seyogyanya atas isu yang diajukan. Dalam penelitian ini, peneliti mengkaji pada norma-norma hukum yang terdapat dalam peraturan perundang-undangan secara sistematis $^{7}$ dan putusan pengadilan yang berkaitan dengan pertanggungjawaban pidana. Pendekatan yang digunakan dalam penelitian ini adalah pendekatan perundang-undangan (statute approach) yaitu pendekatan yang mengkaji tentang asas-asas hukum, norma-norma hukum dan peraturan

\footnotetext{
${ }^{6}$ Marzuki Peter Mahmud, Penelitian Hukum, Jakarta : Kencana Prenada Media Group, 2005, h.59-60.

${ }^{7}$ Mertokusumo Sudikno, Penemuan Hukum, Yogyakarta : Liberty, 2007, h.18.

Sistematika adalah: tatanan atau kesatuan yang utuh yang terdiri dari bagian-bagian atau unsur-unsur yang saling berkaitan erat satu sama lain yaitu kaedah atau pernyataan tentang apa yang seharusnya sehingga sistem hukum adalah kumpulan unsur-unsur yang ada dalam interaksi satu sama lain yang merupakan satu kesatuan yang terorganisir dan kerjasama ke arah tujuan kesatuan.
} 
perundang-undangan serta pendekatan konseptual (conceptal approach) ${ }^{8}$ yaitu mengadakan identifikasi terhadap pengertian-pengertian pokok dasar dalam hukum yakni sunyek hukum, hak dan kewajiban, peristiwa hukum, hubungan hukum dan obyek hukum. Bahan hukum dalam penelitian ini terdiri dari bahan hukum primer, bahan hukum sekunder dan bahan hukum tersier.

Dalam proses pengumpulan bahan hukum, peneliti menggunakan studi dokumen, yaitu mengumpulkan bahan-bahan hukum kepustakaan yang berupa peraturan perundangundangan, buku-buku hukum, jurnal, literatur, dan kamus hukum, kamus bahasa Indonesia dan buku ajar keperawatan. Adapun langkah-langkah pengumpulan bahan hukum meliputi: membaca, mempelajari, mengutip, menghubungkan bahan-bahan hukum dari bahan hukum primer, bahan hukum sekunder serta bahan hukum tersier sehingga menjadi satu kesatuan sehingga mudah dalam pengertian yang disampaikan. Bahan hukum yang berhasil dikumpulkan dan diperoleh untuk penelitian kemudian diolah secara sistematis dan konsisten, selanjutnya dilakukan analisis dalam rangkaian suatu pernyataan-pernyataan yang menggambarkan hasil penelitian dan didasarkan pada masalah yang diteliti. Langkah selanjutnya adalah dilakukan analisis secara teoritikal terhadap bahan-bahan hukum tersebut guna menemukan, memahami dan menjelaskan kekuatan hukum dalam pelimpahan hukum dari dokter kepada ners dari aspek pidana dan perdata.

\section{PEMBAHASAN}

Pada bagian ini, dibahas tiga hal berikut ini yakni Pertama, hubungan hukum antara dokter dengan ners; Kedua, kekuatan hukum pelimpahan wewenang dari dokter kepada ners dari aspek pidana; Ketiga, kekuatan hukum pelimpahan wewenang dari dokter kepada ners dari aspek perdata.

\section{Hubungan Hukum Antara Dokter dengan Ners}

Hubungan dokter-perawat (termasuk perawat profesi atau ners /nurse) adalah satu bentuk hubungan interaksi yang telah cukup lama dikenal ketika memberikan pelayanan kepada pasien. Hubungan dokter dengan ners (nurse) merupakan fenomena sosial yang unik dan menarik untuk dicermati ${ }^{9}$. Kedua profesi dalam bidang kesehatan ini merupakan elemen yang sangat berperan penting dalam penyelenggaraan praktik kesehatan kepada masyarakat karena keduanya memiliki peran yang cukup signifikan. Anwar Kurniadi (dalam Sinar Harapan, 2004) mengatakan bahwa dokter masih menunjukkan sikap hegemoninya dalam praktik kesehatan, hal ini dikarenakan dokter memiliki peran dominan dan utama dalam mendiagnosis dan mengobati penyakit. Sementara peran ners masih kurang diuntungkan. Kondisi ini dalam konteks pendekatan layanan kesehatan kurang menguntungkan bagi usaha pembangunan di sektor kesehatan yang positif. Ketidakseimbangan interaksi antara dokter dan ners (nurse) dapat disebabkan oleh beberapa faktor yaitu:

a. Kebanyakan ners adalah perempuan, sehingga dari ideologi maskulinitas, perempuan pada posisi sub ordinat;

\footnotetext{
${ }^{8}$ Marzuki, Peter Mahmud, Op.Cit.,h.133.

${ }^{9}$ Momon Sudarma, Sosiologi Untuk Kesehatan, Salemba Medika, Yogyakarta, 2008, h. 82
} 
b. Pendidikan, saat ini pendidikan perawat nasih banyak yang D3 dan ners masih sedikit sedangkan dokter minimal S1 dan ditambah pendidikan spesialis, sehingga memberikan ruang hegemoni atau arogansi dari pihak tertentu. Hal ini dapat diatasi dengan peningkatan pendidikan secara profesional;

c. Kesenjangan relasi kekuasaan dokter-ners terkait dengan kewenangan yang dimiliki oleh kedua profesi. Sampai detik ini, dokter adalah satu-satunya pemilik kewenangan untuk mengambil keputusan dalam penentuan sikap terhadap pasien ${ }^{10}$.

Secara garis besar, ners mempunyai peran sebagai berikut yaitu peran perawatan (caring role/independent), peran koordinatif (coordinative/independent) dan peran terapeutik (therapeutic role/ dependent). Peran perawatan dan koordinatif adalah tanggung jawab mandiri, sementara tanggung jawab terapeutik adalah mendampingi atau membantu dokter dalam pelaksanaan tugas kedokteran yaitu diagnosis, terapi maupun tindakan-tindakan medis. Perspektif yang berbeda dalam memandang pasien, dalam praktiknya menyebabkan munculnya hambatan-hambatan teknik dalam melakukan suatu korelasi dalam pelayanan kesehatan. Hambatan dalam hubungan antara dokter dan ners sering dijumpai pada tingkat profesional dan institusional ${ }^{11}$. Perbedaan status dan kekuasaan tetap menjadi sumber utama ketidaksesuaian hubungan tersebut.

Dalam kasus penentuan treatment untuk proses penyembuhan atau penyehatan kondisi seseorang, posisi dokter berada pada tingkat superior ${ }^{12}$. Sementara ners (nurse) diposisikan sebagai orang yang berperan untuk merawat, memelihara pasien dan membantu tugas dokter. Saat ini, hubungan dokter dan ners dalam pemberian asuhan kesehatan kepada pasien merupakan hubungan kemitraan (partnership) yang lebih mengikat dimana seharusnya terjadi harmonisasi tugas, peran dan tanggung jawab dan sistem yang terbuka ${ }^{13}$. Di Indonesia, secara konseptual, hubungan dokter dengan ners sebagai mitra, namun pada kenyataannya ners lebih banyak diposisikan sebagai pembantu dokter. Dokter memberikan perintah (orders) dan ners (nurse) diharapkan mengikuti dan menjalankan perintah tanpa perlu membantah. Bagi dokter kemitraan dengan ners sangat menguntungkan ${ }^{14}$, sedangkan bagi ners sendiri hubungan kerjasama dengan dokter sangat penting apabila ingin menunjukkan fungsinya secara independen. Untuk itu, pendekatan kolaboratif diterapkan secara baik dan benar alam mengatur hubungan kemitraan tersebut. Kolaborasi dalam keperawatan adalah suatu proses dimana ners bekerja dengan dokter untuk memberikan pelayanan kesehatan dalam lingkup praktik profesional keperawatan. Mengutip pandangan Shotridge (dalam Siegler \& Whiteney, 2000:2) mengatakan bahwa pendekatan kolaboratif menekankan tanggung jawab bersama dalam manajemen perawatan pasien. Ners tidak dapat bekerja tanpa berkolaborasi dengan profesi lain ${ }^{15}$.

\footnotetext{
${ }^{10}$ Ibid., h. 83 .

${ }^{11}$ Ibid., h. 85 .

12 Ibid., h. 79.

${ }^{13}$ Nusye KI Jayanti, Penyelesaian Hukum dalam Malpraktik Kedokteran, Pustaka Yustisia, Yogyakarta, 2009, h.49.

${ }^{14}$ J.B. Suharjo B.Cahyono. Membangun Budaya Keselamatan Pasien dalam Praktik Kedokteran, Kanisius , Yogyakarta, 2008, h. 335.

${ }^{15}$ Mimin Emi Suhaemi, Etika Keperawatan, Jakarta : EGC, 2004, h.68
} 
Status yuridis seiring perubahan ners dari perpanjangan tangan dokter menjadi mitra dokter sangat kompleks, tanggung jawab hukum juga akan terpisah untuk masing-masing kesalahan atau kelalaian yanitu malpraktik medis dan malpraktik keperawatan. Perlu adanya kejelasan dari pemerintah maupun para pihak yang terkait mengenai tanggung jawab hukum dari dokter maupun ners terutama berkaitan dengan tindakan medis yang dilimpahkan dari dokter kepada ners.

Terkait pelimpahan wewenang dalam pelayanan kesehatan, dokter dan ners memiliki hubungan hukum, baik pelimpahan wewenang berupa delegasi maupun mandat, dalam hal ini ners tidak dapat mengambil kebijaksanaan sendiri tetapi melakukan tindakan sesuai dengan apa yang didelegasikan atau dimandatkan oleh dokter selaku tenaga medis. Dalam pelimpahan wewenang untuk melakukan tindakan medis, tidak semua tindakan medis dapat dilakukan oleh ners, oleh karena itu mengenai jenis tindakan medis yang dapat dimandatkan ataupun didelegasikan kepada ners dituangkan dalam Undang-Undang Keperawatan di bagian penjelasan pasal 32 ayat (4) dan (5). Adapun penjelasan pasal 32 ayat (4) dan (5) berbunyi :

Ayat (4)

Tindakan medis yang dapat dilimpahkan secara delegatif, antara lain adalah menyuntik, memasang infus, dan memberikan imunisasi dasar sesuai dengan program pemerintah.

Ayat (5)

Tindakan medis yang dapat dilimpahkan secara mandat, antara lain adalah pemberian terapi parenteral dan penjahitan luka.

Menurut penulis, jenis tindakan medis yang disebutkan dalam penjelasan Undang-Undang Keperawatan tersebut belum jelas, penggunaan kalimat "antara lain" mengandung makna dalam penjelasan tersebut hanya menyebutkan beberapa tindakan saja dari sekian banyak tindakan medis yang dapat dilimpahkan kepada ners, dan juga jenis tindakan medis yang dapat didelegasikan hanya kepada ners juga banyak dikerjakan oleh perawat vokasi dan akademik, hal ini berarti belum ada batasan yang jelas dan tegas mengenai batas-batas mandat dan delegasi terkait pelimpahan wewenang dalam pelayanan kesehatan.

Adapun dalam hal pelimpahan wewenang yang dilakukan dokter kepada ners harus memenuhi syarat-syarat sebagai berikut:

a. Penegakan diagnosa, penentuan terapi, serta penentuan indikasi harus diputuskan oleh dokter sendiri. Pengambilan keputusan oleh dokter tidak dapat limpahkan.

b. Pelimpahan tindakan medis hanya diperbolehkan jika dokter tersebut sudah yakin bahwa ners yang menerima pelimpahan itu sudah mampu melaksanakan tugas dengan baik.

c. Pelimpahan wewenang itu harus dilakukan secara tertulis termasuk instruksi yang jelas mengenai pelaksanaannya, bagaimana bertindak jika timbul komplikasi dan sebagainya. 
d. Pada pelimpahan secara mandat, harus ada bimbingan dan pengawasan medis pada pelaksanaannya.

e. Orang yang dilimpahkan berhak menolak apabila ia merasa tidak mampu melakukan tindakan medis tersebut ${ }^{16}$.

Selain itu pelimpahan wewenang secara delegasi, dalam pelaksanaannya harus memenuhi syarat-syarat sebagai berikut :

a. Delegasi harus definitif, artinya delegasi tidak dapat lagi menggunakan sendiri wewenang yang telah dilimpahkan itu;

b. Delegasi harus berdasarkan ketentuan perundang-undangan, artinya delegasi hanya dimungkinkan jika ada ketentuan yang memungkinkan untuk itu dalam peraturan perundang-undangan;

c. Delegasi tidak kepada bawahan, artinya dalam hierarki kepagawaian tidak diperkenankan adanya delegasi;

d. Kewajiban memberi keterangan (penjelasan), artinya delegans berwenang untuk meminta penjelasan tentang pelaksanaan wewenang tersebut;

e. Peraturan kebijakan (beleidsregel), artinya delegans memberikan instruksi (petunjuk) tentang penggunaan wewenang tersebut ${ }^{17}$.

Dalam point c mengatakan bahwa delegasi tidak kepada bawahan, hal ini akan menimbulkan pertanyaan terkait pendelegasian yang terjadi antara dokter dan ners dalam pelayanan kesehatan, dimana banyak asumsi yang menyatakan bahwa ners merupakan bawahan dokter sehingga jika merujuk pada pendapat Philipus Hadjon mengenai syarat delegasi, berarti ners tidak dapat menerima pelimpahan tugas secara delegasi dari dokter dan hanya bisa menerima pelimpahan tugas secara mandat. Lalu bagaimana dengan peraturan perundang-undangan yang melegalkan pelimpahan secara delegasi dari dokter kepada ners.

Pada ruang lingkup kepegawaian, terdapat 2 macam jabatan yaitu jabatan struktural dan jabatan fungsional, jabatan struktural lebih menunjukkan tugas, tanggung jawab, wewenang dan hak dalam rangka memimpin suatu organisasi sedangkan jabatan fungsional lebih menunjukkan tugas, tanggung jawab, wewenang dan hak dalam suatu organisasi dalam pelaksanaan tugas yang didasarkan pada keahlian dan keterampilan, dalam hal ini jabatan fungsional lebih bersifat teknis ${ }^{18}$.

Sama halnya dengan kepegawaian dalam bidang kesehatan, terdapat jabatan struktural dan fungsional. Sehingga menurut penulis maksud dari point c tersebut lebih merujuk/mengarah pada jabatan struktural dokter-ners, dimana dalam jabatan ini dokter tidak dapat memberikan delegasi kepada ners untuk menjalankan tugas dan wewenang dalam rangka memimpin organisasi, karena yang memiliki kewenangan untuk memimpin adalah dokter yang memiliki jabatan struktural lebih tinggi, disini dokter selaku atasan dan ners selaku bawahan (terdapat hierarki kepegawaian) sehingga segala tugas hanya bisa dilimpahkan secara mandat, namun pelimpahan tersebut tidak berkaitan dengan tugas kepemimpinannya. Sebagai contoh, dokter selaku direktur rumah sakit tidak dapat mendelegasikan tugasnya kepada ners, karena tugas dan tanggung jawab memimpin hanya ada pada direktur, dan jika dokter selaku direktur

\footnotetext{
${ }^{16}$ Ibid., h.63

${ }^{17}$ Philipus, M. Hadjon, Perlindungan Hukum Bagi Rakyat Indonesia, Surabaya : Bina Ilmu, 1987.

${ }^{18}$ Sri Hartini, dkk, Hukum Kepegawaian di Indonesia, Jakarta: Penerbit Liberty, 2010.
} 
berhalangan untuk melaksanakan tugasnya menyangkut tugas kepemimpinannya, ia dapat melakukan pelimpahan hanya secara atribusi dan bukan delegasi, pelimpahan ini diberikan kepada orang lain/pejabat di bawahnya dalam hal ini wakil direktur untuk menggantikannya sementara waktu pada saat ia berhalangan.

Dalam menjalankan jabatan fungsionalnya, ners tidak selalu menjadi bawahan dokter, dalam hal ini ners tidak selalu menjalankan fungsi dependent (membantu dokter), namun kedudukan ners juga dapat sejajar dengan dokter, hal ini dapat dilihat dari fungsi Interdependent ners, dimana dalam fungsi ini ners bekerja sama dengan tim keperawatan maupun tim kesehatan termasuk dokter dalam upaya pelayanan kesehatan, sehingga dalam fungsi ini ners dapat menerima pelimpahan wewenang dari dokter secara delegasi karena kedudukan dokter dan ners sejajar, sehingga dapat disimpulkan bahwa pendapat dari Philipus Hadjon mengenai delegasi yang tidak dapat diberikan kepada bawahan berlaku dalam jabatan struktural kepegawaian (dokter-ners) yang memiliki hierarki dalam pelaksanaannya, dan hal ini tidak berlaku dalam jabatan fungsional (dokter-ners) yang lebih mengarah kepada jabatan teknis dimana tugas dilakukan sesuai dengan keahlian dari masing-masing individu dalam suatu organisasi sehingga tidak terdapat hierarki dalam keadaan dan fungsi tertentu dari suatu profesi.

Pelimpahan wewenang dengan cara delegasi atau mandat seharusnya dilakukan secara tertulis melalui surat pelimpahan wewenang. Hal ini menunjukkan bahwa ada hubungan hukum yang lahir dari perikatan yang menimbulkan hak dan kewajiban bagi ners dan dokter sebagai pemberi wewenang. Penggunaan wewenang ini tidak boleh merugikan pihak lain, dan apabila timbul kelalaian dalam pelimpahan wewenang melalui mandat, maka dokter yang bertanggung jawab terhadap kerugian dan kelalaian yang ditimbulkan oleh ners yang diberikan wewenang tersebut. Hal ini dikarenakan dalam pelimpahan wewenang tindakan medis tanggung jawab utama tetap ada pada dokter yang memberi perintah, sedangkan ners hanya bertanggung jawab sebagai pelaksana. Berbeda dengan pelimpahan wewenang melalui delegasi, tanggung jawab terhadap kerugian dan kerugian yang timbul akibat pemberian delegasi ditanggung oleh ners selaku penerima pelimpahan wewenang.

\section{Kekuatan Hukum Pelimpahan Wewenang Dari Dokter Kepada Ners Dari Aspek Pidana}

Dalam bidang hukum, aspek pidana termasuk dalam hukum yang berlaku umum, dimana setiap orang harus tunduk kepada peraturan dan pelaksanaan aturan ini dapat dipaksakan, sehingga setiap anggota masyarakat termasuk ners harus taat, juga termasuk orang asing yang berada dalam wialayah yurisdiksi Negara Republik Indonesia. Dalam pelimpahan wewenang yang dilakukan oleh tenaga medis dalam hal ini dokter kepada ners harus sesuai dengan peraturan perunang-undangan. Dalam melimpahkan tindakan medis kepada ners, dokter berpegangan pada Permenkes Nomor 2052/Menkes/Per/X/2011 tentang Izin Praktik dan Pelaksanaan Praktik Kedokteran, dalam Pasal 23 Ayat (1) menyatakan:

\footnotetext{
"Dokter atau dokter gigi dapat memberikan pelimpahan suatu tindakan kedokteran atau kedokteran gigi kepada perawat, bidan atau tenaga kesehatan tertentu lainnya secara tertulis dalam melaksanakan tindakan kedokteran atau kedokteran gigi”.
} 
Dan bagi ners, dalam menerima pelimpahan tugas dari dokter kepadanya, berpegang pada Pasal 32 ayat (1) dan (2) Undang-Undang Keperawatan:
a. Pelaksanaan tugas berdasarkan pelimpahan wewenang sebagaimana yang dimaksud pada Pasal 29 ayat (1) huruf e hanya dapat diberikan secara tertulis oleh tenaga medis keoada perawat untuk melakukan sesuatu tindakan medis dan melakukan evaluasi pelaksanaannya.
b. Pelimpahan wewenang sebagaimana dimaksud pada ayat (1) dapat dilakukan secara delegatif atau mandat.

Dari kedua paraturan perundang-undangan mensyaratkan pelimpahan wewenang baik berupa mandat maupun delegasi hanya secara tertulis saja, sehingga dari segi pidana pelimpahan wewenang secara tertulis tentunya memilki kekuatan dalam hukum dikarenakan pelimpahan wewenang yang dilakukan dokter kepada ners dengan menulis pada rekam medik dapat dijadikan sebagai alat bukti yang sah menurut macam alat bukti pada hukum acara pidana yang dianut di Indonesia.

Dengan demikian, pelimpahan wewenang secara lisan memiliki kekuatan hukum yang lemah dari segi pidana karena dalam peraturan perudang-undangan yang terkait pelimpahan wewenang tidak mengatur tentang pelimpahan wewenang secara lisan. Pelimpahan wewenang secara lisan yang sering terjadi di ruangan yang dilengkapi dengan CCTV maupun pelimpahan lewat telepon yang terdapat bukti pembicaraannya belum cukup sebagai alat bukti menurut macam alat bukti acara pidana sehingga hal ini tidak menjamin pelimpahan wewenang secara lisan memiliki kekuatan hukum yang kuat. Alat bukti yang sah dalam hukum acara pidana di Indonesia disebut dalam Pasal 184 ayat (1) KUHAP, yaitu : keterangan saksi; keterangan ahli; surat-surat; petunjuk dan keterangan terdakwa.

Berdasarkan Pasal 184 ayat (1) tersebut, bukti elektronik seperti rekaman CCTV dan rekaman telepon tidak masuk dalam alat bukti yang sah. Pendapat lain mengatakan alat bukti elektronik tersebut bisa dimasukkan dalam bagian dari alat bukti yang sah berupa petunjuk. Namun Sumber yang dapat dipergunakan untuk mengkonstruksi alat bukti petunjuk, terbatas dari alat-alat bukti yang secara "limitatif" ditentukan dalam Pasal 188 (2), petunjuk hanya dapat diperoleh dari keterangan saksi, surat, dan keterangan terdakwa ${ }^{19}$, sehingga secara otomatis, bukti elektronik tidak dapat menjadi bagian dari alat bukti petunjuk.

Sesuai dengan perkembangannya, keberadaan bukti elektronik sudah diakui keberadaannya sebagai alat bukti yang sah namun hanya berlaku pada tindak pidana khusus, seperti yang tertuang dalam Pasal 264 Undang-Undang Nomor 20 Tahun 2011 tentang Perubahan Undang-Undang Nomor 31 Tahun 1999 tentang Tipikor dan Pasal 27 UndangUndang Nomor 15 Tahun 2003 tantang Terorisme. Dalam kasus pembunuhan Mirna Salihin, penulis berpendapat bahwa penggunaan rekaman CCTV hanya sebatas bukti penunjang karena selain rekaman CCTV, pada kasus tersebut sudah terdapat alat bukti yang sah menurut pasal 184 ayat (1) KUHP yaitu keterangan ahli, petunjuk dan keterangan saksi. Sehingga

\footnotetext{
${ }^{19}$ M. Yahya Harahap, Pembahasan Permasalahan dan Penerapan KUHAP, Jakarta : $\quad$ Sinar Grafika, 2015. h. 315 .
} 
dalam kasus tindak pidana umum, pemberlakuan bukti elektronik untuk saat ini belum dianggap sah dan belum memiliki kekuatan hukum yang kuat, untuk itu pelimpahan wewenang yang terjadi dari dokter kepada ners secara lisan tidak memiliki kekuatan hukum yang kuat, namun bila dihubungkan dengan tujuan dari hukum pidana yaitu untuk mencari kebenaran materiil, keyakinan hakim yang diutamakan terlepas dari penggunaan alat bukti yang sah maupun alat bukti yang tidak sah.

\section{Kekuatan Hukum Pelimpahan Wewenang Dari Dokter Kepada Ners Dari Aspek Perdata}

Dari segi perdata, hubungan hukum antara dokter dan ners akibat pelimpahan wewenang terjadi karena adanya peraturan perundang-undangan yang berlaku, namun selain itu hubungan hukum antara dokter dan ners dalam pelimpahan wewenang juga dapat terjadi karena adanya perjanjian antara keduanya. Salah satu syarat sahnya suatu perjanjian menurut hukum perdata adalah sepakat, dalam pelimpahan wewenang ini, dokter sepakat memberikan wewenang tindakan medis kepada ners dan ners sepakat untuk menerima wewenang dan melakukan tindakan medis tersebut. Kedua subyek hukum tersebut harus mempunyai kecakapan bertindak dan kewenangan hukum. Ners selaku penerima pelimpahan wewenang harus cakap menurut hukum. Pelimpahan wewenang secara atribusi berarti bahwa ners menerima wewenang karena perikatan yang lahir dari undang-undang, sedangkan perawat dalam pelimpahan wewenang baik secara delegasi atau mandate merupakan perikatan yang lahir karena persetujuan ners sebagai penerima wewenang dengan dokter sebagai pemberi wewenang, hal ini sesuai dengan Pasal 1233 BW, perikatan lahir karena persetujuan dan karena undang-undang. Dengan kata lain, dari segi perdata, hubungan hukum anatar subyek hukum tidak selalu berpatokan pada adanya syarat tertulis atau tidak tertulis. Dalam hukum perdata, hubungan hukum bisa terjadi karena peraturan perundang-undangan dan karena adanya perjanjian yang dibuat oleh subyek yang bersangkutan yang mempunyai kepentingan, dan sahnya suatu perjanjian tertuang dalam Pasal 1320 BW, yaitu:
a. Adanya kesepakatan para pihak;
b. Kecakapan untuk melakukan perbuatan hukum;
c. Adanya sesuatu yang diperjanjikan;
d. Ada kausa yang halal.

Namum dari syarat sahnya suatu perjanjian, menurut penulis dari segi perdata, pelimpahan secara tertulis memiliki kekuatan hukum yang kuat sedangkan secara lisan memiliki kekuatan hukum yang lemah dikarenakan tidak memenuhi salah satu dari keempat unsur sahnya suatu perjanjian menurut Pasal 1320 BW yaitu tidak memiliki kausa yang halal yaitu tidak sesuai dengan apa yang disyaratkan oleh undang-undang yaitu adanya ketentuan syarat tertulis dalam pelimpahan wewenang baik secara mandat maupun delegasi.

Terlepas dari segi pidana maupun perdata, sebenarnya terkait pelimpahan wewenang dalam dunia medis baik itu pelimpahan secara delegasi dan mandat merupakan ranah dari hukum administrasi karena berkaitan dengan kewenangan yang secara tidak langsung ada keterkaitan dengan perizinan suatu tindakan medis dapat dilakukan atau tidak.

\section{E. PENUTUP}

\section{KESIMPULAN}


Berdasarkan pembahasan mengenai kekuatan hukum pelimpahan wewenang dari dokter kepada ners dari aspek pidana dan perdata, dapat disimpulkan sebagai berikut:

1. Dari pandangan Pidana, pelimpahan wewenang pada mandat maupun delegasi yang dilakukan secara tertulis memiliki kekuatan hukum yang kuat, dimana adanya bukti berupa pencatatan pelimpahan wewenang pada rekam medik yang dapat digolongkan dalam alat bukti surat yang merupakan salah satu dari macam alat bukti yang sah menurut hukum acara pidana, sedangkan lisan memiliki kekuatan hukum yang lemah karena pelimpahan secara lisan tidak memiliki alat bukti yang sah. namun bila dihubungkan dengan tujuan dari hukum pidana yaitu untuk mencari kebenaran materiil, keyakinan hakim yang diutamakan terlepas dari penggunaan alat bukti yang sah maupun alat bukti yang tidak sah;

2. Dari pandangan Perdata, pelimpahan secara tertulis memiliki kekuatan hukum yang kuat sedangkan secara lisan memiliki kekuatan hukum yang lemah dikarenakan tidak memenuhi salah satu dari keempat unsur sahnya suatu perjanjian yaitu tidak memiliki kausa yang halal.

\section{SARAN}

Saran yang diberikan peneliti yaitu

1. Apabila dalam praktis pelayanan kesehatan, khususnya menyangkut pelimpahan wewenang, dengan mempertimbangkan banyak hal seperti tenaga medis yang kurang dan dalam keadaan darurat sehingga pelimpahan wewenang secara tertulis tidak memungkinkan dan pelimpahan secara lisan tetap diberlakukan dalam pelayanan kesehatan,.

2. Sebaiknya hal ini menjadi bahan pertimbangan untuk pembuat kebijakan/regulasi sehingga dalam peraturan perundang-undangan dijelaskan mengenai pelimpahan wewenang secara lisan namun dalam batasan dan syarat-syarat yang telah ditentukan oleh pembuat kebijakan sehingga adanya kekuatan hukum dalam pelimpahan tugas tersebut.

\section{DAFTAR PUSTAKA}

\section{Buku}

Abdul Kadir Muhammad, Hukum Perusahaan Indonesia, Citra Aditya Bakti, 2010.

Alexandria Indriyanti Dewi, Etika dan Hukum Kesehatan, Yogyakarta: Pustaka Book Publisher, 2008.

Andi Hamzah, Kamus Hukum, Ghalia Indonesia, 2005.

Bambang Poernomo dalam Muhammad Sadi, Etika dan Hukum Kesehatan, Jakarta: Prenadamedia Group, 2015.

Cecep Triwibowo, Hukum Keperawatan, Yogyakarta: Pustaka Book Publisher, 2010.

Dzulkilfi Umar \& Jimmy P, Kamus Hukum, Jakarta : Graha Media Press, 2012.

E. Sumaryono, Etika dan Hukum (Relevansi Teori Hukum Kodrat Thomas Aquinas), Yogyakarta : Penerbit Kanisius, 2002.

M. Yahya Harahap, Pembahasan Permasalahan dan Penerapan KUHAP, Jakarta : Sinar Grafika, 2015.

Marzuki, Peter Mahmud, Penelitian Hukum, Jakarta: Kencana Prenada Media Group, 2005.

Philipus, M. Hadjon, Perlindungan Hukum Bagi Rakyat Indonesia, Surabaya : Bina Ilmu, 1987. 
Prodjohamidjojo Martiman, Penerapan Pembuktian Terbalik dalam Delik Korupsi, Bandung : Penerbit Mandar Maju, 2001.

Ridwan, Hukum Administrasi Negara, Jakarta: PT RajaGrafindo Persada, 2006.

Safitri Hariyani, Sengketa Medik :Alternatif Penyelesaian PerselisihanAntara Dokter dengan Pasien, Jakarta: Diadit Media, 2005.

Salim \& Nurbani Erlies, Penerapan Teori Hukum Pada Penelitian Tesis dan Disertasi, Jakarta : Raja Grafindo Persada, 2013.

Santi Dewi Sartika, Pelimpahan Wewenang dalam Rancangan Undang-Undang Keperawatan, 2013.

Shidarta, Hukum Perlindungan Konsumen Indonesia, Jakarta: PT.GramediaWidiasarana Indonesia, 2000.

Soekidjo Notoatmojo, Etika dan Hukum Kesehatan, Jakarta : Rineka Cipta, 2010.

Sofyawan Dahlan, Hukum Kesehatan Rambu-rambu Profesi Dokter, Semarang: Universitas Diponegoro, 1999.

Sri Praptianingsih, Kedudukan HukumPerawat dalam Upaya Kesehatan di Rumah Sakit., Jakarta: RajaGrafindo Persada, 2006.

Sudikno Mertokusumo, Penemuan Hukum, Bandung : Citra Aditya Bakti, 2009.

Sutarno, Hukum Kesehatan, Malang : Setara Press, 2014.

Titik Triwulan \& Shinta Febrian, Perlindungan Hukum Bagi Pasien, Jakarta : Prestasi Pustaka, 2010.

Triwibowo, Etika dan Hukum Kesehatan, Yogyakarta: Nuha Medika, 2014.

Veronica Komalawati, Peranan Informed Consent Dalam Transaksi Terepeutik (Persetuajuan Dalam Hubungan Dokter dan Pasien); Suatu Tinjauan Yuridis,Bandung: PT.Citra Aditya Bhakti, 2002.

Yulianingsih Kodim, Konsep Dasar Keperawatan, Jakarta: Trans Info Media, 2015.

\section{Jurnal}

Anthon. Susanto, Keraguan dan Ketidakadilan Hukum (Sebuah Pembacaan Dekonstruktif), Jurnal Keadilan Sosial, Edisi 1, 2010.

Arrie Budhiartie. Pertanggungjawaban Hukum Perawat Dalam Penyelenggaraan Pelayanan Kesehatan Di Rumah Sakit, Jurnal Hukum, Fakultas Hukum Universitas Jambi. Vol. 11 No. 2, 2009.

Djaelani, Pelimpahan Kewenangan Dalam Praktik Kedokteran Kepada Perawat, Bidan

Secara Tertulis Dapat Mengeliminasi Tanggung Jawab Pidana \& Perdata, Jurnal Hukum Kesehatan, Ed pertama, 2008.

Delik News, Perawat Tolong Pasien Dipidana,(On Line),http//www.desentralisasi kesehatan, 2009, Diakses Tanggal 15 September 2017.

M. Fauzan, Pesan Keadilan DI Balik Teks Hukum Yang Terlupakan, Varia Peradilan, Vol.XXVI, Oktober 2010.

Made Subawa. Pemikiran Filsafat Hukum Dalam Membentuk Hukum. Sarathi : Kajian Teori dan Masalah Sosial Politik, Asosiasi ilmu politik Indonesia Denpasar, Vol. 14(3), 2007.

\section{Peraturan Perundang-undangan}

Undang-Undang Republik Indonesia Nomor 29 Tahun 2004 tentang Praktik Kedokteran (Lembaran Negara Republik Indonesia Tahun 2004 Nomor 116, Tambahan Lembaran Negara Republik Indonesia Nomor 4431). 
Undang-Undang Republik Indonesia Nomor 36 Tahun 2009 tentang Kesehatan (Lembaran

Negara Republik Indonesia Tahun 2009 Nomor 144, Tambahan Lembaran Negara

Republik Indonesia Nomor 5063).

Undang-Undang Republik Indonesia Nomor 44 Tahun 2009 tentang Rumah Sakit (Lembaran

Negara Republik Indonesia Tahun 2009 Nomor 153, Tambahan Lembaran Negara

Republik Indonesia Nomor 5072).

Undang-Undang Republik Indonesia Nomor 36 Tahun 2014 tentang Tenaga Kesehatan

(Lembaran Negara Republik Indonesia Tahun 2014 Nomor 298， Tambahan

Lembaran Negara Republik Indonesia Nomor 5607).

Undang-Undang Republik Indonesia Nomor 38 Tahun 2014 tentang Keperawatan

(Lembaran Negara Republik Indonesia Tahun 2014 Nomor 307, Tambahan

Lembaran Negara Republik Indonesia Nomor 5612).

Permenkes Nomor 2052/Menkes/Per/X/2011 tentang Izin Praktik dan Pelaksanaan Praktik Kedokteran.

Kode Etik Keperawatan.Kode Etik Kedokteran.

Kitab Undang-Undang Hukum Pidana (KUHAP).

Kitan Undang-Undang Hukum Perdata. 